\title{
THE UNCERTAIN DOCTRINE OF PART PERFORMANCE
}

\author{
Susy Frankel
}

This article is about the doctrine of part performance and its application in New Zealand's law of contract. In order to be enforceable contracts for the disposition of land must be in writing and must be signed by the person against whom the contract is enforced. Where these requirements have not been met the courts have evolved the doctrine of part performance to enable a contract to be enforceable where that is equitable. This article outlines the doctrine of part performance as found in New Zealand and argues that it is so uncertain that its existence does not benefit litigants or would be litigants. The article concludes that the difficulties with the doctrine of part performance mean that it is not a clear and effective mechanism again the misuse of the writing requirement and, therefore, adds to other reasons to repeal the writing requirement for contracts for the sale of land.

Since joining the Faculty of Law at Victoria University of Wellington in 1997, I have several times taught aspects of the law of contract, including the subject of this article, with David McLauchlan. It is an honour to write this short piece as a tribute to such an outstanding teacher and researcher who I have been very lucky to have as a colleague.

\section{INTRODUCTION}

The doctrine of part performance in New Zealand has the appearance of being a settled area of law. Since the principles that were laid down in Tipping J's judgment in TA Dellaca Ltd v PDL Industries Ltd ${ }^{1}$ were accepted in Court of Appeal cases ${ }^{2}$ there is a degree of truth to that proposition. ${ }^{3}$ However, one of the two Court of Appeal decisions that adopted the Dellaca test slightly modified the test. ${ }^{4}$ Also, the Dellaca test has relatively easily been applied in a number of

* Professor of Law, Victoria University of Wellington, susy.frankel@ vuw.ac.nz.

1 TA Dellaca Ltd v PDL Industries Ltd [1992] 3 NZLR 88 (HC).

2 Mahoe Buildings Ltd v Fair Investments Ltd [1994] 1 NZLR 281 (CA) and Fleming v Beevers [1994] 1 NZLR 385 (CA).

3 Previous High Court cases took a different approach. See for example Boutique Balmoral Ltd $v$ Retail Holdings Ltd [1976] 2 NZLR 22 (SC) and Hinterleitner v Heenan (1990) 1 NZ Conv 190 (CA).

$4 \quad$ Fleming $v$ Beevers, above n 2. 
High Court decisions, ${ }^{5}$ although, the doctrine is quite complicated. The decisions setting part performance's parameters leave a number of questions unanswered. This article discusses those questions and concludes they make the doctrine uncertain and not settled law.

The need for a plaintiff to rely on part performance arises from the modern application of the Statute of Frauds requirement that contracts for the sale of land be in writing. Part performance is the equitable counterpart to relieve the sometimes harsh consequences of the application of that writing requirement. The existence of the writing requirement has been controversial and led to the Law Commission recommending its repeal. ${ }^{6}$ It has not been repealed. Instead it was reborn as part of the Property Law Act 2007. This article discusses the parameters of part performance and suggests that ultimately, although the doctrine provides a fascinating legal maze, its retention is problematic. The only reason it is required is because the writing requirement for contracts for the sale of land can lead to unfairness or inequity. The better approach, however, would be to repeal the writing requirement for contracts for the sale of land and, thus, also remove the only reason that litigants need rely on part performance. This article concludes that the doctrine of part performance is problematic and ill-suited to the 21 st century. ${ }^{7}$

\section{THE WRITING REQUIREMENT FOR CONTRACTS FOR THE SALE OF LAND}

The doctrine of part performance only comes into play if there is a contract "such as would have been enforceable but for the Act". ${ }^{8}$ The Act's requirements are now found in the Property Law Act 2007 which provides: ${ }^{9}$

(1) A contract for the disposition of land is not enforceable by action unless -

(a) the contract is in writing or its terms are recorded in writing; and

(b) the contract or written record is signed by the party against whom the contract is sought to be enforced.

This section is in plainer English than its predecessors, found in the Contracts Enforcement Act $1956^{10}$ and the original Statute of Frauds. ${ }^{11}$ It is, however, primarily the same in its core

5 See for example Te Namu v Kapoor HC Napier CIV 2008-441-186, 12 June 2008 and Welsh v Gatchell [2009] 1 NZLR 241 (HC).

6 Law Commission Repeal of the Contracts Enforcement Act 1956: A Discussion Paper (NZLC PP30, 1997).

7 A similar point is made in GHL Fridman "The Necessity for Writing in Contracts Within the Statute of Frauds" (1985) 35 UTLJ 43.

8 TA Dellaca Ltd v PDL Industries Ltd, above n 1, at 109.

9 Property Law Act 2007, s 24.

10 Contracts Enforcement Act 1956, s 2(2) (now repealed). 
requirements that contracts for the sale of land must be in writing and signed by the person against whom the contract is enforced (the defendant). There is much case law about what amounts to writing, whether documents can be joined to form a written contract ${ }^{12}$ and what is a signature. The latter issue has given rise to the doctrine of the authenticated signature fiction. ${ }^{13}$ Those difficulties arguably give rise to reasons to repeal the writing requirement. ${ }^{14}$ While those issues are not, the subject of this article, ${ }^{15}$ this article adds to those reasons.

It is important to distinguish between contracts for the sale of land, to which the writing and signature requirements apply, and the actual formal passing of title, that is the conveyance of the land, that also has a writing requirement. ${ }^{16}$ The suggestion that the writing requirement be removed only relates to the writing requirement for the contract. The actual conveyance or transmission of title is a different matter and no suggestion is made that it should not be in writing.

The requirements of writing and a signature are not exclusive to contracts for the disposition of land. The Contracts Enforcement Act 1956 also applied to guarantees, but that was repealed with the passing of the Property Law Act in 2007. ${ }^{17}$ Contracts relating to matrimonial or relationship property, for example, must be in writing to be enforceable. ${ }^{18}$

Other transmissions of property are sometimes required to be in writing. An example is the requirement in the Copyright Act 1994 that an assignment of copyright must be in writing to be

11 Section 4 of the Act for the Prevention of Frauds and Perjuryes 1677 (commonly known as the Statue of Frauds, now repealed) provided: "No action shall be brought ... upon any contract or sale of lands, tenements or hereditaments, or any interest in or concerning them ... unless the agreement upon which such action shall be brought, or some memorandum or note thereof, shall be in writing and signed by the party to be charged therewith or some other person thereunto by him lawfully authorised".

12 See Timmins v Moreland Street Properties Ltd [1958] Ch 110 (CA) and Saunderson v Purchase [1958] NZLR 588 (SC). In England and Wales now all of the terms must be in one contract. See Law of Property (Miscellaneous Provisions) Act 1989 (UK), s 2(1).

13 See TA Dellaca Ltd v PDL Industries Ltd above n 1, 98 for a summary of the doctrine. See also Sturt $v$ McInnes [1974] 1 NZLR 729 (SC).

14 These reasons formed the basis of the Law Commission's recommendation for repeal of the then Contracts Enforcement Act 1956, see Law Commission, above n 6.

15 However, others argue they are reasons to repeal the writing requirement. See Law Commission, above n 6 See also GHL Fridman, above n 7. Others do not support the repeal, see the Queensland Law Reform Commission Statutes of Frauds and Limitations Act of 1876; Working Paper no 4 (QLRCW4, 1969); Manitoba Law Reform Commission Report on the Statute of Frauds (Report No 41, 1980); Law Reform Commission of British Columbia Report on the Statute of Frauds (LRC 33, 1977).

16 Property Law Act 2007, s 25, which substantially re-enacts the Property Law Act 1952, s 49A (now repealed).

17 Contracts Enforcement Act, s 2(1)(d) (now repealed).

18 Property (Relationships) Act 1976, ss 21F and 21H. 
effective. ${ }^{19}$ Notably, however, that requirement applies to the assignment of copyright and it is not the equivalent of a Statute of Frauds contract requirement. It is the equivalent of the Property Law Act 2007 conveyance requirement. ${ }^{20}$ Any contract to assign copyright can be oral, but the transmission is not effective until there is a written assignment. Therefore a plaintiff could obtain an order for a written transmission of copyright to be executed where the plaintiff is the equitable owner of copyright. ${ }^{21}$

The original purpose of the equitable doctrine of part performance was to ameliorate the sometimes harsh effects of the application of the strict legal rule requiring writing. Part performance only applies to situations where there is a contract. Part performance cannot be used as a means to say a contract exists; it is not a tool to prove contract formation. Rather, the New Zealand approach is to determine if a contract exists and, if the writing and signature requirements are not fulfilled, then turn to the issue of part performance.

\section{PART PERFORMANCE IN NEW ZEALAND}

The doctrine of part performance is expressly retained under the Property Law Act 2007. ${ }^{22}$ A successful part performance claim makes a contract enforceable for the disposition of land even though the contract is not in writing and signed by the defendant. ${ }^{23}$ One function of the writing requirement is that writing, if available, can be the best evidence of the existence of a contract. In a part performance case the written evidence requirement is substituted by part performance being the evidence of the contract. ${ }^{24}$ This is one of the rationales that courts give for the doctrine of part performance. This rationale, however, sits awkwardly with the modern application of the doctrine. Before part performance is considered an oral contract must be established. This oral contract is often described as an otherwise enforceable oral contract. ${ }^{25}$ Proof of that oral contract must exist independently of the part performance analysis. Acts of part performance do, in a sense, evidence the existence of a contract. The existence of the contract coupled with part performance is precisely why it is inequitable not to allow the contract to be enforced. However, the formation evidentiary function is not the role that acts of parts performance have in the analysis under the Dellaca text.

19 Copyright Act 1994, s 114.

20 Property Law Act 2007, s 25.

21 See for example, Western Front Ltd v Vestron Inc [1987] FSR 66 (Ch).

22 Property Law Act 2007, s 26.

23 In the England and Wales the Law of Property (Miscellaneous Provisions) Act 1989 has meant that part performance is no longer an effective doctrine. This is because purely oral land agreements are void under s 2 of that Act so there is no contract in existence to be "part performed".

24 See Fleming $v$ Beevers, above n 2, at 393. Tipping J describes the evidentiary aspect of part performance as "important but subsidiary".

25 See step 1 of the test set out in TA Dellaca Ltd v PDL Industries Ltd above n 1, at 110. 
Rather, as Tipping J explained in Fleming v Beevers, it is the requirement of substitute proof for the writing requirement. In Fleming $v$ Beevers Tipping $\mathrm{J}$ summarised the reasons for the doctrine of part performance: ${ }^{26}$

... over the years two concepts have been said to underpin the doctrine of part performance ... equity will not allow the Statute of Frauds itself to become an instrument of fraud ... equity takes the view the defendant is not charged upon the contract alone but also upon the equities arising from part performance; and ... the acts of part performance are treated for probative purposes as a satisfactory substitute for the statutory requirement of writing. It is the concept of substitute proof which led to the need for the acts of part performance, of themselves, without reference to the evidence of the oral contract, to point to the probability of a contract relating to the land and consistent with that alleged.

These rationales are important because if the parameters of the doctrine do not reflect these rationales the doctrine is arguably too unwieldy and uncertain.

Tipping J, in Dellaca, laid down the test for part performance as follows: ${ }^{27}$

1. Was there a sufficient oral agreement such as would have been enforceable but for the Act?

2. Has there been part performance of that oral agreement by the doing of something which:

(a) clearly amounts to a step in the performance of a contractual obligation or the exercise of a contractual right under the oral contract; and

(b) when viewed independently of the oral contract was, on the probabilities, done on the footing that a contract relating to the land and such as that alleged was in existence.

3. Do the circumstances in which that part performance took place make it unconscionable (fraudulent in equity) for the defendant to rely on the Act?

Part 2 (a) of the test reflects Tipping J's conclusion that an act of part performance must be in performance of a contract not merely in reliance on a contract. ${ }^{28}$ Prior to Dellaca there was a body of law that was considerable, in both volume and inconsistencies, about whether an act of part performance must be in performance of a term of a contract or merely in reliance on, or only somehow referable, to the alleged contract. ${ }^{29}$

26 Fleming $v$ Beevers above n 2, at 393.

27 TA Dellaca Ltd v PDL Industries Ltd above n 1, at 110.

28 Ibid, at $108-109$.

29 See for example Maddison v Alderson (1883) 8 App Cas 467 (HL) at 479, per Lord Selborne LC, giving the formula that the act of part performance must be "unequivocally referable to some such agreement as that alleged". The leading 'modern' English case was Steadman v Steadman [1974] 2 All ER 977 (HL). The Lords all said different things, but the majority took the broad view that part performance could be an act in 
The Dellaca test was cited with approval and adopted in two subsequent Court of Appeal cases, Mahoe Buildings Ltd v Fair Investments Ltd ${ }^{30}$ and Fleming $v$ Beevers. ${ }^{31}$

The key legal issue in Mahoe Buildings Limited was that the act of part performance must have been performed by the party seeking to enforce the contract, that is the plaintiff. ${ }^{32}$ After making this point, however, the Court then discussed whether payment of money by a tenant in possession can be part performance. The Court concluded such a payment can be part performance, but that it is equivocal. ${ }^{33}$ This is true, but it is a rather peculiar comment in the case that was before the Court. On the facts, it was the landlord's, not the tenant's, part performance which was at issue. This is perhaps just an instance of the Court choosing a bad example. However, it is arguably an illustration of how even an appellate court can be confused over on the complexities of the doctrine.

In Fleming $v$ Beevers, the Court, in a judgment delivered by Tipping J, tweaked limb 2(b) preferring the phrase "consistent with that alleged" to "such as that alleged". ${ }^{34}$ The reason for this was the conclusion that "such" was too restrictive where a contract had many parts and such a contract could be described as a composite transaction, rather than a single transaction. This distinction raises some difficulties which are discussed below.

Subsequent High Court cases have applied the Dellaca test. ${ }^{35}$ However, there remain some problems and unanswered questions despite Tipping $\mathbf{J}$ saying the test brings considerable certainty to part performance. ${ }^{36}$ These are:

- the requirement that it must be unconscionable for the defendant to rely on the statutory writing requirement; and

- $\quad$ the distinction made in Fleming $v$ Beevers between single term and composite transactions.

Each of these is discussed in the next part.

reference or reliance, not restricted to performance. See also Tipping J's summary of the law in TA Dellaca Ltd $v$ PDL Industries Ltd, above $\mathrm{n} 1$.

30 Mahoe Buildings Ltd v Fair Investments Ltd, above $\mathrm{n} 2$.

$31 \quad$ Fleming $v$ Beevers, above $\mathrm{n} 2$.

32 Mahoe Buildings Ltd v Fair Investments Ltd above n 2, at 287.

33 Ibid, at 288.

34 Fleming $v$ Beevers, above $\mathrm{n} 2$.

35 Welsh v Gatchell [2009] 1 NZLR 241 (HC); Perkins v Purea (2008) 9 NZCPR 266 (HC) at [80].

36 TA Dellaca Ltd v PDL Industries Ltd above n 1, at 108. 


\section{THE PROBLEMS WITH THE APPLICATION OF PART PERFORMANCE IN NEW ZEALAND}

\section{A The Unconscionable Part of the Dellaca Test}

Because part performance is an equitable doctrine it involves an element of something unconscionable in equity. The doctrine has evolved because the Statute of Frauds, and its successors, were used wrongly. That is, the technical requirements could be used to make a contract unenforceable when one party had performed part of an orally agreed contract. The second part of the test, set out above, establishes whether the plaintiff has completed any acts in performance of the oral contract. The second part does not require that there be something unconscionable that is independent from the existence of either the oral contract or the plaintiff's acts of part performance. It is because of the part performance that not enforcing the contract would be inequitable. The very existence of the acceptance that acts of part performance give the plaintiff an equitable right to enforce a contract suggests that the third step is redundant. Put another way, the third step requirement is perhaps superfluous because the unconscionable conduct is the attempt to rely on the writing requirements when there is a partly performed oral agreement. The unconscionable circumstances referred to, in the third limb, are the circumstances that give rise to a positive answer to the first and second parts of the test. The third step serves the function of focusing the inquiry back on the defendant's conduct. However, that focus is probably unnecessary as a separate step. At best the third step does no harm, if it is read as repeating the earlier parts of the test, but if it undermines them this could be an issue.

Few cases have discussed the third step in detail. One exception is an appeal made to the High Court in Brabazon Properties Ltd v Nixon. ${ }^{37}$ In that case the contract at issue was an oral agreement to lease premises. The parties had entered into a written lease which had expired and the dispute related to a new oral agreement with an increased rental, which the respondent had paid. Laurenson J found that there was an oral agreement and that the payment of increased rental amounted to an act of part performance of that agreement. The appellant (who was defendant at first instance) argued that the agreement should not be enforced because there was nothing unconscionable about the appellant's refusal to put the agreement in writing. The appellant submitted: ${ }^{38}$

that his action in finally declining to sign the lease had really been caused as a result of his frustration in trying to get the respondent to commit himself to the terms of the deed of lease. During this time the respondent had seemingly prevaricated and had sought changes to the arrangement. In those circumstances it could not, therefore, be said that he acted unconscionably in finally refusing to sign the lease and then let the property to a third party

37 Brabazon Properties Ltd v Nixon (1999) ANZ Conv R 378 at 383.

38 Ibid, at 382. 
In relation to step 3 of the Dellaca test Laurensen J said: ${ }^{39}$

I have to agree with the appellant's submission that the mere fact that the appellant had accepted the higher rental may not, by itself, make it unconscionable for him to have later declined to sign the lease, particularly in view of the difficulties which he had experienced with the respondent. There is, however, in my view, another factor from which it may be inferred that the appellant acted unconscionably. On my reading of the evidence it seems clear that the appellant knew that the respondent was in a quandary. The respondent was not able to determine whether he required the lease for himself or for the purposes of an inducement to a possible purchaser. Either way it was the case that the respondent was relying on having the advantage of the lease. At no stage did the appellant seek to terminate the arrangement. He stated that he didn't consider there was a binding arrangement, but for the reasons already canvassed this does not accord with the facts. In my view it was unconscionable for the appellant not to sign the lease for three [sic] reasons:

1. Up to the point of declining he had always apparently been willing to proceed with the lease. He had given no indication of any intention to withdraw from the arrangement.

2. He was aware of the respondent's dependence on having a lease.

3. He had received the respondent's acceptance of the terms of the lease.

4. He had, in the interim, received the benefit of the increased rental.

Laurenson J dutifully applied the third step of the test. His Honour's reasoning, set out above, turns the focus back on the defendant, but none of the four reasons add anything of substance to the conclusion that there has been part performance. Intention to withdraw from the arrangement would only be effective if the agreement could be cancelled. Intention to cancel is not the cancellation test for a contract. ${ }^{40}$ The awareness of the respondent's dependence on the lease is not necessary for there to be an equity raised by the respondent's part performance. Even if the appellant was not directly aware of the respondent's situation, that should not make a difference to the outcome when there was an awareness of the part performance. The respondent's acceptance of the terms of the lease is a part of the basis for the finding that there was an agreement in the first place. Receiving the benefit of the rental is the flipside of the part performance of payment.

The problem with making a separate finding of unconscionable conduct is that it risks finding some acts of part performance are only enforceable if the defendant is scurrilous in some way. Whereas the basis of the doctrine is that the plaintiff ought to be able to rely on any acts of parts performance because those acts have benefited the other party to the contract, the defendant.

Ibid, at 384.

40 Contractual Remedies Act 1979, s 7(1). See Francis Dawson and David W McLauchlan The Contractual Remedies Act 1979 (Sweet \& Maxwell (NZ) Ltd, Auckland, 1981). 
The Court of Appeal has paid very little attention to the third step in the cases. In Dellaca the plaintiff's claim failed at the second step, so the third factor was not examined. Tipping J, however, said: ${ }^{41}$

Many people might well consider that it is unconscionable and unfair in general terms to shelter behind the Contracts Enforcement Act 1956 if there has been an oral agreement to sell land. Many would regard it as morally offensive and contrary to good conscience to rely on the absence of writing but the Contracts Enforcement Act remains a central part of the law relating to contracts for the sale and purchase of land. It is not in my judgment for the Courts seriously to undermine what is clearly the policy of the Act by expanding the doctrine of part performance into some general species of estoppel. Obviously the doctrine contains an element of estoppel but it involves more than that. In short it requires the contract to have been carried into effect at least in part by the party seeking to enforce it in such a way that it is unconscionable for the other party to rely on the Act.

Tipping J's aim in adding the third limb seems to have, therefore, been to distinguish the boundaries of part performance from a broad notion of estoppel. This, however, is already achieved in the other parts of the test.

In Fleming $v$ Beevers the part performance analysis ends with the conclusion that because there have been acts of part performance: ${ }^{42}$

Mr Beevers is charged not upon the contract alone, but also upon the equities arising by dint of the fact that Miss Fleming took steps partly to perform the composite oral transaction in circumstances where it would be wholly inequitable to allow Mr Beevers to rely upon the absence of writing to avoid his obligation to devise.

In essence this conclusion shows that because the second step was made out the Court considered that the third step was also made out and did not see it as necessary to independently reason why that was so.

The presence of the third limb suggests, however, that the answer could be no, even if the second limb is fulfilled. There is no case that has concluded this. That is probably sensible because such a conclusion would undermine the core rationale of part performance; that it is the performance that gives rise to the equity. There are no acts of the plaintiff's part performance that the defendant can dismiss on the basis of them not being very detrimental to the plaintiff. Such an approach would require the courts to rank acts of part performance on some notion that some are less important than others. While some acts of part performance may cause less detriment to a plaintiff than others, the basis of the doctrine of part performance should not logically give way to such an evaluative

41 TA Dellaca Ltd v PDL Industries Ltd, above n 1, at 108-109.

42 Fleming $v$ Beevers, above n 2, at 394. 
approach. If it were to do so the doctrine would be even more unacceptably complex and unpredictable.

\section{B Composite Transactions}

Another feature of part performance which detracts from its certainty is the discussion in Fleming $v$ Beevers regarding composite transactions. Tipping $\mathbf{J}$ explained that the facts before him gave rise to an example of a composite transaction not a "single term contract" for the disposition of land. ${ }^{43}$ There were many parts to the agreement between the parties, including an arrangement to buy the land together; how the purchase was to be financed; how title was to be taken between them; that Mr Beevers would guarantee Miss Fleming's mortgage; that she would indemnify him; and that each would leave to the other his or her interest by will. ${ }^{44}$

But what is a single term contract? A contract for sale of one piece of land is likely to have many terms. Tipping $\mathbf{J}$ seems to have meant a single transaction.

A good reason to call the contract in Fleming $v$ Beevers a composite contract was because an act of part performance of one aspect of the contract would mean that there had been part performance in relation to the whole. It would be inequitable to divide a whole agreement between parties up into artificially separate transactions. On the facts of Fleming $v$ Beevers the acts of part performance in question all related to the "land" at issue. There was, therefore, no need to ask the question what if the act of part performance was an act which did not point to the land aspect of the contract. Could such an act be an act of part performance? The argument against this is that the requirement that the contract be in writing is because of the land so, therefore, the act of part performance should directly relate to the land.

This issue had been at the centre of the House of Lords decision in Steadman v Steadman. ${ }^{45}$ There the majority substantially widened the doctrine by holding, although notably on an obiter dicta basis, that the act of part performance could be about an aspect of the contract that did not relate directly to the land. ${ }^{46}$ The Court of Appeal in Fleming $v$ Beevers agreed with this approach (although, the Court noted that it did not need to decide the point on the facts before it). ${ }^{47}$ An added complexity was that the only non-land aspect of the Fleming $v$ Beevers composite transaction was held not to be part of the contract. ${ }^{48}$ Fleming $v$ Beevers has thus left the law uncertain because it has

43 Ibid, at 390. See also Steadman v Steadman [1974] 2 All ER 977 (HL) at 989.

44 Fleming v Beevers, above n 1, at 392.

45 Steadman v Steadman, above n 43.

46 Ibid, at 981 per Lord Reid, and at 989 per Viscount Dilhorne.

47 Fleming v Beevers, above n 2, at 390-394.

48 Ibid, at 390. 
opened the possibility that a non-land related aspect of the contract can amount to an act part performance, but such a finding has not been made in the New Zealand courts.

Altering the facts of Fleming $v$ Beevers illustrates why the Court's conclusion is problematic. The part of the dispute that was not found to be in the so-called composite transaction related to a grand piano. Ms Fleming claimed that she and Mr Beevers had an agreement that he would leave her the piano. The Court found that there was no evidence of this. But assume that it was part of the composite transaction and also assume that part of the composite transaction was that Ms Fleming and $\mathrm{Mr}$ Beevers had agreed she could move the piano to a property that she owned independently of him. If the piano was so moved would that act of part performance be enough to say there had also been part performance in relation to the land? One might suggest no, but that is precisely what the obiter statements in Fleming $v$ Beevers suggest is possible. Thus, the doctrine is very uncertain.

On the one hand, the concept of a composite transaction is important because aspects of some agreements, like the one in Fleming $v$ Beevers, are so co-dependent they should not be separated. However, this is contingent on any set of facts being found to amount to a composite transaction. On the one hand, disparate elements should not be joined together too easily if that makes part performance too easy. On the other hand, if part performance can relate to any element of the transaction, land or otherwise, and the dealings between the parties are grouped together because they are the total dealings between the parties, then that would seem just. The difficulty is the court's approach potentially encourages plaintiffs to add on non-land aspects in order to create such an "oral package deal". 49 Arguably the difference between such a composite contract and other contracts is somewhat arbitrary, but the consequence is that one sort may give rise to part performance and the other not. Consequently, the doctrine cannot be said to be certain. To adapt Tipping J's words from another context, "the ripples of composite contracts can spread too widely". 50

\section{AN ALTERNATIVE APPROACH}

An alternative approach is that taken in England where there has been a substantial modification of the writing requirement. There, all terms must be in one document and there was a complete removal of the availability of part performance. ${ }^{51}$ The New Zealand Law Commission's view was that the writing requirement should be repealed. Parliament has not taken up the Law Commission's

49 Steadman v Steadman, above n 42, at 989 per Viscount Dilhorne.

50 TA Dellaca Ltd v PDL Industries Ltd, above n 1, at 109.

51 See of Property (Miscellaneous Provisions) Act 1989, s 2 repealing the Property Law Act s 40 following a report by the Law Commission Transfer of Land: Formalities for Contracts for Sale Etc of Land (No 164 HC2, 1987). See an explanation of the history in Actionstrength Ltd (t/a Vital Resources (formerly t/a Morson Alltrades)) (company number 2761631) v International Glass Engineering I Gl E SpA [2003] UKHL 17. 
recommendation, so the doctrine of part performance continues. As it remains part of the law then the third step of the Dellacca test, the unconscionable requirement, and the issues relating to composite transactions need to be clarified. Such clarification is perhaps not impossible, but is fraught with difficulties making part performance very detailed and quite unpredictable. Thus, clarification is a less desirable approach than removal of the availability of part performance and (or) repeal of the writing requirement. Even if the writing requirement remains part of New Zealand law, there is a good argument that part performance should not be available because of its uncertainties which are not easily repaired.

\section{CONCLUSION}

The doctrine of part performance is the equitable means to combat the harshness of the writing requirement. Part performance is, however, not a settled area of law and is too legally complex to provide certainty. It invites potentially expensive litigation. The cases are few, but that might be because the litigation costs are too high not because the issues are not worthy. Removal of the writing requirement for the sale of land would remove the function of the doctrine of part performance. This would be a good solution rather than trying to fix the doctrine. This article has not traversed the many arguments in favour of repeal of the writing requirement. These have been done elsewhere. ${ }^{52}$ The doctrine of part performance should be excised from New Zealand law.

52 Law Commission, above n 6. 